\begin{abstract}
Iranica
Abstracta Iranica Revue bibliographique pour le domaine irano-aryen

Volume 32-33 | 2013

Comptes rendus des publications de 2009-2010
\end{abstract}

\title{
Michael Alram. A new drachm of Ardashir I
}

\section{Nikolaus Schindel}

\section{(2) OpenEdition}

\section{Journals}

Electronic version

URL: http://journals.openedition.org/abstractairanica/40452

DOI: 10.4000/abstractairanica.40452

ISSN: 1961-960X

\section{Publisher:}

CNRS (UMR 7528 Mondes iraniens et indiens), Éditions de l'IFRI

\section{Printed version}

Date of publication: 1 December 2013

ISSN: 0240-8910

\section{Electronic reference}

Nikolaus Schindel, « Michael Alram. A new drachm of Ardashir I », Abstracta Iranica [Online], Volume 32-33 | 2013, document 136, Online since 01 July 2016, connection on 28 September 2020. URL : http://journals.openedition.org/abstractairanica/40452; DOI : https://doi.org/10.4000/ abstractairanica.40452

This text was automatically generated on 28 September 2020 .

Tous droits réservés 


\title{
Michael Alram. A new drachm of Ardashir I
}

\author{
Nikolaus Schindel
}

\section{REFERENCES}

Michael Alram. «A new drachm of Ardashir I ». in : Philippe Gignoux, Christelle Jullien, Florence Jullien, éds., Trésors d'Orient, Mélanges offerts à Rika Gyselen. Paris, Association pour l'avancement des études iraniennes, 2009, p. 21-26. (Cahier Studia Iranica, 42)

1 The author discusses a silver drachma of the Sasanian ruler Ardashir I (224-241) from mint B ("Hamadan"). It features a frawahr-symbol on the tiara. According to the author, it refers to Ardashir's coronation as King of Kings in 224.

\section{AUTHORS}

NIKOLAUS SCHINDEL

Österreichische Akademie der Wissenschaften, Wien 